\title{
Határátlépések, térbeélések
}

\section{Migránsok a transznacionális térben}

Napjainkban a migráció a társadalomkutatók kiemelt témájává vált. Különösen nagy érdeklódésre tart számot a munkavállalás céljából történó migráció, az a jelenség, amelynek során az emberek lakóhelyüktól távol vállalnak munkát, nagyon gyakran egy másik országban, saját országuktól akár nagyon messze keresve jó munkavállalási lehetóséget. A jelenség nyilván nem újkeletú: különbözó korszakokban, különbözó térségekben az éppen adott politikai, gazdasági, társadalmi helyzetnek megfelelóen alakult a vándorlás iránya, dinamikája, a benne részt vevók összetétele.

A napjainkban különösen megnövekedett vándorlási kedv magyarázatának sok összetevője van, ugyanis olyan világméretű trendről beszélhetünk, amelynek specifikumai egyrészt a globális makrotényezőktől, másrészt pedig az egyes országokra, térségekre, régiókra, településekre jellemző társadalmi-kulturális jellemzőktől függően alakulnak. A kelet-európai térségben azt tapasztaljuk, hogy a rendszerváltás utáni munkamigráció intenzívvé válása beleilleszkedik azokba a világméretü trendekbe, amelyek a globalizáció korát jellemzik: a határokon átnyúló gazdasági/társadalmi/kulturális folyamatok, a nemzetközi szabályozások serkentik és elősegítik azt, hogy bárki átléphesse saját országa határait, és szülőföldjétől távol keressen munkát, ott, ahol saját megítélése, elképzelése, tervei, lehetőségei szerint jobb körülményeket talál. Nagyon gyakran azt is eldöntheti, hogy a külföldi munkát milyen hosszú idöre vállalja, hogyan alakít ki egy sajátos életformát, amely ideiglenesen vagy hosszabb időre a vándorlás, az ide-oda mozgás életmódját jelenti majd számára. Nem hanyagolhatók el ugyanakkor azok a szempontok sem, amelyek a határok átlépésének kulturális meghatározottságait adják: milyen az a praxis, amely a határok átlépését szabályozza, vannak-e ennek közösségileg szabályozott mechanizmusai, vagy ez ma már egyénileg szervezett gyakorlat. Vannak-e a kibocsátó közegnek olyan sajátos kulturális hagyományai, amelyek a mai globális tendenciák mellett is megadják az illető helyre jellemző kilépési, mobilitási formákat?

\section{A határokon átlépő ember - a migráció mint az emberi létállapot egyik lehetséges formája}

Napjaink emberének szembeszökően intenzívvé váló vándorlása sok kérdést vet fel, ezeknek egyike magának a mozgásnak mint emberi léthelyzetnek a problematikáját is elötérbe helyezi. Felveti ugyanis azt a kérdést, hogy melyik a természetes állapota az embernek: a helyhez kötöttség vagy a mobilitás. Melyiket tekinthetjük ,valódi” létformának: az egy helyen élést vagy az egyik helyröl a másikra történő vándorlást? A territorializmus szemlélete a kultúrák földhözkötöttségét mint természetes állapotot kezeli: az identitáskonstrukciók is ennek megfelelően „,földhöz kötöttek”. Az individuumok 
ilyenformán akkor lehetnek részesei valamilyen „kötöttségnek”, amennyiben egyetlen helyhez tartoznak csupán, ez az egyetlen hely pedig a társadalmi csoporthoz, a kultúrához való kötődésüket is biztosítja. Nem véletlen, hogy ehhez a szemlélethez olyan metaforikus fogalmak kapcsolódnak, amelyek a társadalomtudományoktól sem idegenek, és amelyek az ember természetes létállapotát a helyhez kötöttség állapotaként tételezik: a gyökér, a fa metaforái jelennek meg, amelyek egyfajta biológiai-növényi létállapothoz kapcsolják az identitások építésének egyetlen lehetséges módozatát. Innen továbblépve, a helyváltoztatás is a földhöz kötöttség metaforái által nyer értelmezést: a vándorlás, a mozgás az elgyökértelenedés metaforájával válik megragadhatóvá, ez pedig a kiszakítottság és a számkivetettség jelentéseit generálja (Malkki, 2006).

A territorializmus szemléletével ellentétbe állítható a deterritorializáció szemlélete, amely arra hívja fel a figyelmet, hogy a kizárólag egyetlen térhez köthető identitáskonstrukciók meglazulnak, az individuumnak lehetősége van arra, hogy átlépje a fizikai, politikai és kulturális határokat, ezzel együtt pedig kialakítson egy „kultúrák közti teret”, amely új identitáskonstrukciók lehetőségét is hordozza (Niedermüller, 2005). A térhez kötődés kizárólagossága fellazul, a mozgás nem természetellenes állapot többé. A deterritorializáció elméletéhez a transznacionalizmus elmélete kapcsolódik, mely azokat a megváltozott életformákat teszi vizsgálat tárgyává, amelyek napjaink globalizált világában alakultak ki. A transznacionális életforma lehetővé teszi, hogy az emberek egyszerre több térhez is kapcsolódjanak ugyanabban az időben, identitásukat nemcsak egy térhez való kapcsolódásuk által építsék, hanem azt ebben a köztes térben alakítsák ki. A migráló ember számára ez azt jelenti, hogy a határok átlépése, a kimozdulás, a helyváltoztatás által nem kell föltétlenül gyökértelenné válnia, kiszakadnia. Létrehozhat egy olyan sajátos, transznacionálisnak nevezhető életformát, amely nem a negatív megítélések, a valamitől való megfosztottság mentén válik leírhatóvá. A két vagy több hely között történő mozgás akár hosszú ideig tartó életformát is jelenthet, és új, tartós identitások kialakítását is lehetővé teszi (Glick Schiller, Basch és Szanton, 1997; De Haas, 2010; Schiffauer és Werner, 2004).

A rendszerváltás után nagy lendülettel elinduló kelet-európai külföldi munkamigráció dinamizmusa mit sem csökkent az utóbbi években. Különböző országokban, különböző térségekben megvannak a nyilvánvaló különbségek - a sok hasonló vonás mellett -, de annyi mindenképpen nyilvánvaló, hogy egy olyan társadalmi jelenséggel állunk szemben, amelynek vizsgálata, a kutatások tapasztalata egykori fogalmaink felülértékelését is maga után vonja. Ha röviden vázolni szeretném, melyek ezek a sajátos jellegek, amelyek a deterritorializáció és a transznacionalizmus jeleit mutatják, és amelyek a nemzetközi trendekhez is közelítik térségünk migrációs gyakorlatát, a következő jellegzetességeket kell megemlítenem (természetesen csak vázlatosan, a teljesség igénye nélkül).

Az elmúlt évtizedekben azt tapasztalhattuk, hogy lazulnak a mozgást, a határok átlépését gátló tényezők. Ezek a tényezők igen sokrétűek, ide sorolható például az utazás egyszerübbé válása. Lerövidül az utazási idő, olcsóbb is lesz, a fizikai távolságok tehát könnyen legyőzhetők, az utazással járó anyagi megterhelés is jelentősen csökken. Talán még fontosabb az itt említetteknél az a tényezö, hogy a távolságok könnyü áthidalása csökkenti azt az érzést, ami az egyik hely elhagyásából fakad, vagyis nem kelti az elszakadás érzését. Amennyiben a helyváltoztatás nem jelent áthidalhatatlan akadályokat, a migráns úgy hagyja el kibocsátó környezetét, hogy bármikor visszatérhet oda, tehát nem kell az otthontalanság tartós állapotával szembenéznie.

Nem elhanyagolható tényező a kommunikációs lehetőségek javulása sem: a migráló ember könnyedén tud kapcsolatot tartani mindkét hellyel, legyen fizikailag épp bármelyikhez kötve. A kommunikációs eszközök mindenki számára elérhetőek, és a bármikori kapcsolatfelvétel lehetősége szintén az elszakadás érzését enyhíti. A határok átjárhatókká váltak: ez vonatkozik most már nemcsak a fizikai határok átlépésére, hanem a politikai 
határok könnyebb átjárhatóságára is. Ebben a tekintetben maguk a kelet-európai rendszerváltások jelentették a nagy változást, de nem hanyagolhatók el azok az 1989 óta napjainkig bekövetkezett, a határok átlépését könnyítő szabályozások sem, amelyek egyszerübbé és „természetessé” tették az egyik országból a másikba vándorlást. Az elmúlt két és fél évtized alatt ezen a téren sok olyan feloldás történt, amely a külföldi munkavállalók számára lehetővé tette, hogy migrációs gyakorlataikat leegyszerüsítsék, és a „normalitás", a mindennapiság egyik formájaként éljék meg. Fontos tényezőként említendők ugyanakkor azok a globális változások, amelyek a külföldi munkavállalás legalizálása terén történtek. Több ország megnyitotta munkaerőpiacát (vagy annak valamelyik szegmensét) a külföldi munkavállalók előtt, és ez jórészt véget vetett a feketemunkának, ez az új helyzet pedig, a közvetlen rendszerváltás utáni helyzethez viszonyítva, hozzájárult ahhoz, hogy a munkavállalás céljából külföldre vándorlók számára a határok átlépése könnyebbé és magától értetődőbbé váljon.

Ejtsünk még szót a továbbiakban a transznacionális migráció néhány fontos aspektusáról. A transznacionális elméletek a múlt század utolsó évtizedében erösödtek meg, mintegy következményeként azoknak a változásoknak, amelyek a globalizáció nyomán következtek be. Témánk szempontjából azon szegmenseknek van most nagyobb jelentőségük, amelyek a migrációval való összefüggésben jelennek meg. Azok a migránsok, akik hosszabb ideig tartózkodnak egy, az otthonuktól távoli fizikai-társadalmi-kulturális térben (vagy több alkalommal váltogatják helyüket két vagy több tér között), képesek lesznek arra, hogy mindkét helyhez kötődjenek - szimultán módon, ugyanabban az időben. Nem kell tehát teljesen megszakítaniuk a kibocsátó közeggel kapcsolataikat akkor sem, amikor hosszabb ideig tartózkodnak a befogadó ország környezetében. Ugyanakkor létrehozhatnak kapcsolatokat a befogadó közegben is, és ez nem jelenti az otthoni környezettől való elszakadást. A szimultán beágyazódás mindkét közeg esetében működhet - természetesen a két környezet más-más szegmenseihez kapcsolódva, és eltérö intenzitással. A témával kapcsolatos antropológiai elemzések (Glick Schiller, Basch és Szanton, 1997) jegyzik meg, hogy a migránsoknak nem kell asszimilálódniuk a befogadó környezetbe, de nem is kell kiszakadniuk a kibocsátó közegből. A kultúraváltás ebben az értelemben nem kötelező, a migráns mozoghat egy olyan „kultúrák közötti térben”, amely mindkét irányba lehetővé teszi a kötődéseket. A határok átlépése nem jelent tehát elgyökértelenedést, hisz a migránsnak nem kell „kitépnie a gyökereit”, távollétében ugyanis kapcsolatokat tart fenn az otthoni közeggel, informálódik kibocsátó környezetének számára fontos hírei felől, hazautazik a kiemelt eseményekre, de akár intézményes kapcsolatokat is müködtethet. Ezzel egyidőben úgy van jelen a befogadó társadalomban is, hogy ott is „benne él” a világban, intézményesített formában, szabályozott módon, amely lehetővé teszi számára, hogy „idegenségét” ne a teljes elutasítás és hárítás formájában kelljen megélnie.

A bemutató következő részében arra törekszem, hogy a fenti kijelentéseket saját kutatásaim terepén, az ott szerzett tapasztalatokkal illusztráljam.

\section{Transznacionális jegyek napjaink székelyföldi munkamigrációjában}

A rendszerváltás utáni időszakban a Székelyföld térségében nagyon hamar beindult a külföldi munkamigráció. A folyamat azóta sem lanyhult, mondhatni, dinamikája csak erősödött: egyre több társadalmi réteget érint, az életkori kategóriák tekintetében is nagy a változatosság. Férfiak és nők egyaránt részt vesznek a folyamatban, családosak és családalapítás elött állók, különböző iskolázottságú egyének, falusi és városi környezetböl, egyre többen választják az otthontól távol történő, hosszabb-rövidebb ideig tartó munkavégzést. Az okok és célok igen változatosak, mint ahogy a külföldi munkaeröpiacon betöltött pozíciók is 
nagyon sokfélék. A célországok köre az idő folyamán kibővült, és az is nagyon változatos képet mutat, hogy ki mennyi időt tölt külföldön, hány alkalommal megy ki, mennyi időre tervezi ezt az életformát. A csíkszeredai KAM - Regionális és Antropológiai Kutatások Központja keretében már a kilencvenes évek első felében módszeresen kezdtük vizsgálni a térségből külföldre irányuló munkamigrációt. Később a Sapientia - EMTE társadalomtudományi tanszéke keretében létrejött munkacsoport is bekapcsolódott a vizsgálatokba. Vizsgálódásaink mögött a kulturális antropológia szemlélete áll, módszereink is ehhez a diszciplínához kapcsolódnak. Munkánk során több száz beszélgetést folytattunk a térségből külföldre vándorló munkamigránsokkal, arra törekedve, hogy az általuk elmondottakat belehelyezzük a térség társadalmi-kulturális kontextusába, ekképp próbálva megrajzolni napjaink térségi migrációjának legfontosabb jellemzőit. Több csoportos és egyéni projekt zajlott le, publikációk egész sora született a témában (Bodó, 1996, 2007, 2009; Biró, 1994, 1995). A továbbiakban az általunk végzett munkamigrációs kutatásoknak csupán arra a szegmensére szorítkozom, amelyek a határok átlépésének változó tendenciáira, illetve a jelenség transznacionalizálódásának jeleire utalnak.

\section{A kilencvenes évek migrációs gyakorlatának néhány jellemző vonása}

Első lépésben arra szeretnék utalni, ami a székelyföldi térség munkamigrációjának sajátos jegyeként értelmezhető. Olyan vidékröl van szó, ahol az otthonról távol történő munkavállalás nem újkeletü gyakorlat. A térség migrációjának történetét áttekintve (Oláh, 1996) azt látjuk, hogy az itt lakók számára időről időre, az adott politikai-gazdasági körülményeknek megfelelő módon, az életvezetés különböző felmerülő kérdéseinek megoldására megfelelö gyakorlatnak bizonyult az otthontól távoli munkakeresés. Ha az otthoni közeg nem tette lehetővé, hogy a térség kulturális elöírásainak megfelelően lehessen kialakítani az életmódot, akkor az emberek - a közösségi normák elöírásainak megfelelően - valahol távol kerestek munkát: a környező vagy távolabbi városokban, az ország más térségeiben, vagy egyenesen külföldön. Sokszor választották ezt az életmódot annak érdekében, hogy el tudják érni a közösségi elvárásoknak megfelelő életszínvonalat.

Ennek fényében nem meglepő, hogy 1989 decembere után nagyon hamar beindult a külföldi, munkavállalási célú migráció. Ahogy a határok megnyíltak, hirtelen nagyon sokan elindultak külföldre munkát keresni. Első, a témára irányuló kutatásunkban azt vizsgáltuk, hogy a vendégmunka milyen hatást gyakorol a kibocsátó környezetre. Azt láttuk, hogy ennek az első időszaknak a gyakorlata az előző években felhalmozott hiányok gyors pótlására törekszik (új fogyasztási cikkek beszerzése, lakások felszereltségének javítása, a családi gazdaság eszközparkjának bővítése), de az életvezetést igen kevéssé befolyásolja. Ezzel a megfigyeléssel szorosan összefügg az a kutatási tapasztalat, amely jelen téma szempontjából fontosnak mutatkozik: a külföldi munkavállalás során megtörtént a határok fizikai átlépése, de azzal együtt azok mentális megerősítése is végbement. Hogyan zajlott le ez a gyakorlat? A migránsok ebben az időszakban egy hosszú, elzárt korszak után léptek ki egy másik világba. Mindennapi életvezetésük, gondolkodásmódjuk olyannyira eltért a külföldön tapasztaltaktól, hogy szinte minden találkozási pont a másság érzetét hívta elő belőlük. Ez az időszak, az akkori migrációs szándékok, célok, még igen kevéssé kedveztek annak, hogy a két világ bármilyen módon közeledhetett volna egymáshoz. Az is hozzájárult ehhez a fizikai és mentális távolságtartáshoz, hogy a székelyföldi külföldi munkavállalók a kilépések első évtizedében olyannyira kizárólagosan az otthoni világ hiányainak pótlására összpontosítottak, hogy az idegen világ igen kevés felületével alakítottak ki érintkezési pontokat. De ha lebontjuk ezen magatartás összetevőit, még sok aspektusa kirajzolódik az elhatárolódás, a határmegvonás gyakorlatának. Nézzünk meg néhányat ezek közül. 


\section{Utazás, a fizikai határok átlépése}

Az utazás, a fizikai határok konkrét átlépése sok akadályba ütközött a rendszerváltást közvetlenül követő korszakban. A székelyföldi migránsok fő célországa a kilencvenes években Magyarország volt, de még ennek a határnak az átlépése sem volt mindig zökkenőmentes. Evvröl évre különböző, alig követhető hivatalos eljárások léptek életbe, amelyek szabályozták a határátlépést: megfelelő pénzösszeggel, biztosítással, meghívóval, bevallott vagy bizonyított szándékkal és csak korlátozott időszakra lehetett kilépni az országból - még olyan helyre is, ahol nem volt vízumkényszer. Változott az is, hogy mikor mennyi pénze lehetett vagy épp nem lehetett az utazónak, mit volt ajánlatos vagy épp nem ajánlatos vinnie, melyik indok volt elfogadható vagy titkolnivaló, mikor az átlépésnél az utazási szándék felől kérdezősködtek a hivatalosságok. A megszorítások időnként átjátszhatók voltak, de akkor is megnehezítették a munkavállalók helyzetét. Ezekkel a változó, és olykor a hatóságok szeszélyei szerint is müködő szabályokkal a kilépés ,a nagy kalanddá" vált, amelyre stratégiákat kellett kidolgozni, kooperációs mechanizmusokat bevetni, rögtönözni és időnként kockáztatni. Ilyen körülmények között a kilépés semmiképp sem volt „természetes”, „magától értetődő”, a mindennapok részét képező gyakorlat. A határok ilyen módon nem leépültek, hanem egyfajta, a munkavállaló (akinek külföldi munkavégzési szándékát jól el kellett titkolnia) számára nehezen legyőzhető akadály szimbólumaivá váltak. Egy ideig az országból kilépők számára a külföldön megengedett tartózkodás időtartama harminc napra korlátozódott. (Ennél hosszabb időszakra már vízumkérelmet kellett benyújtani, de ez igen idő- és pénzigényes müvelet volt, ennél is nehezebbnek bizonyult viszont megfelelő indokot igazolni. Feketemunka esetén pedig ez teljesen lehetetlen volt.) A vendégmunkások természetesen megtalálták a módját a hosszabb külföldi tartózkodásnak: elég volt akár néhány órára visszautazni a határ túloldalára, hogy egy újabb harmincnapos időszakra biztosítsák maguknak a szabályos külföldi tartózkodást. A hatóságokkal való sikeres összejátszásról is beszámoltak interjúalanyaink: az összegyüjtött útleveleket valaki átvitte a határon, és fizetség ellenében beleütötték a megváltó pecsétet. Amikor pedig épp egy olyan szabályozás lépett életbe, amelynek megfelelően száz márka költőpénzt kellett felmutatni a határátlépés fejében, a külföldre járó autóbuszok soförjei rutinos, jól bejáratott módon osztották szét utasaik között a „,mutogatós százmárkásokat”, melyeket az utasok az átlépés után visszaszolgáltattak a gépkocsivezetőnek, aki jól eltette azokat a következő hasonló alkalomra. Sorolni lehetne még azokat a praktikákat, amelyekkel sikeresen áthidalták a határátlépés elé támasztott akadályokat. Bár a fenti módozatokat bevált módon, rutinosan alkalmazták, ezek a technikák nem váltak a határok „lebontásának” eszközeivé, hanem inkább megerösítették azokat.

\section{A kommunikáció lehetőségei}

A kommunikációs lehetőségek ebben az időszakban igen nehézkesek voltak, ugyanakkor költségesek. A mobiltelefon elterjedtsége még nem volt jellemző, az internetes kommunikáció lehetőségei sem léteztek még ezekben az években. A kapcsolattartás az otthoniakkal tehát komoly akadályokba ütközött. A vendégmunkás ritkán engedte meg magának az időigényes és költséges telefonálást, más módja a kapcsolattartásnak pedig nem volt. A hagyományos levélírás nyilván mindenkinek rendelkezésére állt, de a lassúság miatt nem tette lehetővé a naprakész informálódást az otthoniakról. Egyik beszélgetőpartnerünk azt mesélte el, hogy miután több hetes távollét után végre telefonon felhívta őt Magyarországon dolgozó férje, mindketten annyira elérzékenyültek, hogy végül is csak sírni tudtak a telefonba, mondani már semmit sem bírtak egymásnak. A kilépés tehát 
gyakorlatilag hosszú időre megszakította a kapcsolatot a két világ között, nem volt mód arra, hogy az otthonától távol tartózkodó vendégmunkás értesüljön az otthoni hírekröl, eseményekröl, nem is beszélve az intenzív társadalmi bennlevés gyakorlatáról, amire egyáltalán nem nyílt lehetőség.

\section{Munkavégzés az idegen világban}

Még volt egy nagyon fontos oka annak, hogy a két világ közti szimbolikus határvonal megerösödött a mindennapi vendégmunkás gyakorlat által: a külföldi munka illegális volta. Ebben a korszakban ugyanis a munkavállalók nagy része nem hivatalosan dolgozott Magyarországon (vagy másutt). A feketemunka sok olyan problémát vetett fel, amelynek kivédésére hasonlóan kidolgozott (vagy még sokkal megterhelöbb) technikákra volt szükség, mint a fizikai határok átlépése tekintetében. A feketén dolgozó külföldi munkavállaló állandó rejtőzködésre kényszerült, és már csak ezért sem tudott olyan transznacionális életmódot kialakítani, amelyről az előző fejezetben szó esett (erre majd csak egy későbbi időszakban nyílik lehetőség). Rejtőzködni kellett a hivatalosságok elől, amelyek ellenőrzésétől, leleplezésétől állandóan tartani kellett. A leleplezés komoly következményekkel járt, legrosszabb esetben a kitiltást vonta maga után, amely épp a vendégmunka célját hiúsította meg hosszú időre. Megbetegedni sem volt ajánlatos, mert a feketén dolgozó munkavállalónak semmilyen egészségügyi ellátás nem járt. A vendégmunkás ezzel a rejtőzködő életformával semmiképp sem találhatta meg azt a módot, amely által a kinti világba úgy léphetett volna be, hogy ne érezze szüntelenül kívülállónak magát.

A munkavégzéssel kapcsolatos határmegvonásnak volt még egy sajátos vonása. A vendégmunkás legtöbb esetben azzal a határozott céllal érkezett külföldre, hogy a kint keresett pénzzel pótolja családi háztartása hiányait, amelyek a rendszerváltást megelőző időszakban igencsak felhalmozódtak. Ezek a határozott célok ma már nem látszanak olyan komoly, nagy céloknak, de ha megpróbálunk visszahelyezkedni annak a korszaknak a körülményei közé, mindjárt érthetővé válik, hogy ezeknek a célkitüzéseknek a konkrét realitásokon túl igen erős szimbolikus jelentésük is volt. A színes televízió, az automata mosógép, a gyereknek szánt farmernadrág, a feleségnek vásárolt divatos cipő, a dobozos üdítő és a csokoládé, amivel minden rokont, barátot, ismerőst, szomszédot meg kellett ajándékozni a hazatéréskor, nem kis erőfeszítést és lemondást kívánt a munkamigráns részéről, ugyanakkor az otthoni életvezetési, kapcsolattartási normák kötelező parancsaként müködött. Ezek az elvárások szabták meg a külföldön dolgozó vendégmunkás számára a munkaidőt, a szabadidőt és annak eltöltési módját, az egész külföldi tartózkodás megszervezési módozatát. Ennek következtében a vendégmunkás minden idejét munkára fordította, szabadidőt gyakorlatilag nem engedélyezhetett magának. Nem volt ideje tehát arra, hogy „élje” a kinti világot, azt megismerje, beélje azokat a lehetőségeket, amelyek által szorosabb kapcsolatot alakíthatott volna ki annak bármilyen szegmensével. A külföldön keresett pénz szigorú beosztása csak tovább fokozta ezt a helyzetet: a megkeresett pénzt az utolsó fillérig az otthoni hiányok betöltésére kellett fordítani, a kapcsolattartási normáknak eleget tenni kívánó igyekezet szerint beosztani. Így minden kinttartózkodás az otthoni célok elérésére irányult, és nem adott lehetőséget a külföldi környezet „meghódítására”, amely a határok lazítását tette volna lehetővé.

Ezáltal egy mentális határ képződött a munkamigráns és környezete között, amelyet még súlyosbított a környezet elutasító, lekezelö, lenéző volta. A Magyarországon ideiglenesen munkát vállaló székelyföldi migráns esetében mindezt még tetézte az a jelenség, amelyet elemzéseinkben a „lerománozás” müszóval illettünk. Mit takar ez a fogalom? A többszáz beszélgetés, amelyet munkamigránsokkal készítettünk, szinte mindegyikében 
arról számol be az interjúalany, hogy Magyarországon az ottaniak románoknak nevezték őket. Ez a székelyföldiek identitástudatát igen érzékenyen érintő „lefokozás”, eltávolítás nagymértékben hozzájárult ahhoz, hogy a székelyföldiek erős határvonalat érezzenek a helyiek és önmaguk között, ennek lebontására az adott körülmények mellett igen kevés mód kínálkozott. A, ,lerománozás” visszautasítása olyan gesztusokat, nyelvi és akár fizikai agressziót eredményezett, ami elégtételként, a visszatérés után otthon elmesélhető hőstörténetként jól funkcionált ugyan, de a közeledést nem szolgálta. Egyik beszélgetőpartnerünk igen vehemens átéléssel idézte fel azt a bizonyára gyakran elmesélt történetet, amikor az építőtelepen, ahol dolgozott, egyik helyi munkatársa „,belekerült a malterosládába", miután másként nem lehetett őt meggyőzni arról, hogy Székelyföldről érkezett munkatársa nem román.

\section{Mentális elhatárolódások}

Említésre érdemes még a mentális elhatárolódásnak az a gyakorlata, amellyel a hazatérők narrációiban találkoztunk. A kinti tapasztalatok elmesélése során számtalanszor fordultak elő olyan nyelvi fordulatok, amelyek a lefokozás eszközeivel éltek, vagy az egyes történeteket lekerekítve, a lezáró epizódokkal azokat mintegy hőstörténetté alakították át, amely által a mesélő került a narratívában a győztes helyzetébe. İgy a narratívák szintjén, az elmesélés folyamán az „ők” és a „mi” világa közti határvonalat húzták meg. Ezek az epizódok nemcsak egyszerüen a különbségeket mesélték el, hanem az elhatárolódásokat építették.

A fentiekben felsorolt fizikai és mentális határépítések tehát sokkal inkább az otthoni és a kinti világ különbözőségét erősítették meg, semmint enyhítették, leépítették volna azokat.

\section{Változások a munkamigrációban - a kétezres évek új trendjei}

A továbbiakban a kilencvenes évek után folytatódó migrációs gyakorlat módosulásait vázolom, kiemelve azokat az aspektusokat, amelyek trendszerü változásokat mutatnak. Jelesen a transznacionális migráció ismérveinek a megjelenéséről van szó, amelyek alapvetően megváltoztatták a Székelyföldről külföldre irányuló munkamigráció jellegét. Mindenekelött azt kell megjegyeznem, hogy a migráció dinamikája tovább növekedett, a fiatal generáció egyre markánsabban jelent meg a külföldön munkát keresők körében, a nők részvétele is egyre inkább növekvő tendenciát mutatott. A célországok száma is nőtt, és már nem Magyarország lett a migránsok első számú célpontja. A folyamat eme változásának okai nagyon összetettek (gazdasági, politikai, társadalmi), de ezen írás keretében ezek részletezésére nem vállalkozhatom. Célom csupán az, hogy a makro- és mikrotársadalmi folyamatok előterében zajló migrációs trendek változásainak azokra az aspektusaira figyeljek, amelyek a vizsgált régióra jellemző módon mutatják azokat a változásokat, amelyek a migrációs folyamat két végpontja (kibocsátó és befogadó közeg) közti kapcsolat múködési módjára jellemzőek. Az előző fejezetben a kilencvenes évek trendjeit jelezve azt láttuk, hogy a migráció a két világ, a saját és az idegen, az ők és a mi elhatárolódásának mechanizmusait termelte ki. A kétezres évek elejétöl már megváltozni látszik ez a kép. A határvonalak meglazulnak, az elhatárolódási tendenciák gyengülnek, a munkamigránsok praxisaiban sokkal több az idegenség, a másság iránti megengedő, vagy akár elfogadó gesztus. Érvényes mindez a fizikai határok átlépésére is, és a mentális határvonalak lebontására is. Ha a fentiekben jellemzett, kilencvenes évekbeli trendek átalakulását figyeljük, a következő kép rajzolódik ki. Ez a kép természetesen igen vázlatos lesz, hisz arra törekszik, hogy az évek során felhalmozódott kutatási tapasztalatokból 
kiválasszon olyan trendszerü, de szemléletes összetevőt, amely a változások jeleit hordozza magán, és szemlélteti a határvonalak meggyengülését, valamint a transznacionális migrációs formák irányába történő elmozdulást.

\section{Határátlépés - új szabályokkal}

Az utazási lehetőségek napjainkra lényegesen megváltoztak. A legfontosabb jellemzők egyike a gyors helyváltoztatás lehetősége, mely távoli országokba utazás esetében is alkalmat ad a két hely közötti kapcsolat viszonylag egyszerü megteremtésére. Az utazás anyagilag is elérhetőbb, habár még ma is ez az egyik legnagyobb akadálya a munkamigránsok gyakoribb hazalátogatásának. Fontos tényező a térbeli távolságok leküzdésében, hogy az országhatárok átlépésére régebb jellemző elriasztó és körülményes hivatalos procedúrák lényegesen leegyszerüsödtek. Ma már a határok átlépése nem támaszt olyan akadályokat, amelyek leküzdéséhez az előbbi fejezetben említetett technikákra lenne szükség. Ez pedig azzal jár, hogy a határátlépés körülményes és kockázatos vállalkozásból egyszerü, mindennapi eljárássá változott. Az utazás ilyenformán nem ,a nagy kilépés” többé, hanem egy „normális”, természetes művelet. A kilépés-visszalépés leegyszerüsödött volta az otthontól való eltávolodást és visszatérést olyan természetes állapottá változtatta, amely nem jár kockázatokkal a határok átlépése tekintetében.

\section{Kommunikáció a két világ között - a kapcsolatépítés új formái}

Szó esett a kommunikációs lehetőségekről is, ami jelentős tényező a két világ közti kapcsolattartás szempontjából. Nem mindegy, hogy a migránsnak az otthonától való eltávozás esetében meg kell-e szakítania kapcsolatát a kibocsátó környezettel, vagy megvan a lehetősége a rendszeres kommunikációnak. A kilencvenes évek óta elterjedt új kommunikációs eszközök ma már mindenki számára elérhetőek, anyagi vonatkozásban sem jelentenek legyőzhetetlen akadályt a kapcsolatot müködtetők számára. A családtagok napi kapcsolatot tudnak kialakítani a mobiltelefonok, az internet segítségével, ezek gyorsak és mindig kéznél vannak. Az előbb említettem annak a fiatal házaspárnak az esetét, amelynek tagjai a férj külföldre utazása nyomán csak hetekkel később kerültek telefonközelbe egymással. Hadd említsek itt most egy másik történetet, amely jól jelzi a változást. Egy fiatal lány szövi be migrációs történetébe a következő epizódot: szezonális mezőgazdasági munkát vállalt egy nyugat-európai országban, de ez a munka számára túl nagy megpróbáltatást jelentett, mivel otthon nem szokott hozzá az ilyen munkavégzéshez. Egyfajta próbának, kihívásnak tekintette ezt a vállalkozását, és semmiképpen sem akart megfutamodni. Nagy segítséget jelentett számára ugyanakkor, hogy a mezőn is ott volt a zsebében mobiltelefonja, otthonról gyakran felhívták családtagjai, barátai. Sokszor ez a hívás nem is jelentett beszélgetést, csak egy megcsengetést, jelzését annak, hogy az otthoniak gondolnak rá, együtt éreznek vele. Példák sokaságát lehetne sorolni, amelyekben a kapcsolattartásnak ez a leegyszerüsödött volta lehetőséget teremt arra, hogy a migráló egyén az otthontól távoli létet ne a teljes elszakadás állapotaként élje meg.

De nemcsak a személyes kapcsolatok müködtetése terén mutatkoznak meg a változás jelei. Migráns beszélgetőpartnereink gyakran számoltak be arról is, hogy nemcsak a családtagokkal, barátokkal tartanak intenzív kapcsolatot, hanem az otthoni világ különbözö más szegmensei felől is tájékozódnak, mert ezáltal nem veszítik el a kapcsolatot az otthoni történésekkel, a fizikai távolság ellenére sem „esnek ki” az otthoni eseményekből. A lokális hírekről az otthoniak tájékoztatják őket, de a tágabb régió eseményeit is követik a helyi vagy regionális hírportálokon. Beszámolnak például arról, hogy miként értesül- 
nek otthoni lakóhelyük híreiről; olyan beszélgetőpartnerünk is volt, aki elárulta, hogy amíg otthon élt, a közéleti-politikai hírek nem nagyon érdekelték, de amióta külföldön lakik, figyelemmel követi azokat az internet adta lehetőségek által. Azért van erre szüksége, mert így nem érzi magát annyira távol az otthoni történésektől, bármikor vissza tud kapcsolódni az otthoni közegbe. Ezzel párhuzamosan az is megfigyelhető (habár a beszélgetésekben ritkábban tértek ki erre), hogy figyelnek a befogadó közeg történéseire is.

Szólni kell ugyanakkor azokról a lehetőségekről is, amelyeket a közösségi média által lehet kihasználni. A migránsok külön csoportokat hoznak létre a befogadó országban élő honfitársaikkal, vagy saját régiójukbeli migránsokkal. De az otthoniakkal történő gyors, közvetlen hangú kapcsolatoknak is ez lett a legmegfelelöbb eszköze. Van, aki szülővárosa webkameráját mindennap megnézi, hogy lássa élőben a helyszínt, milyen a mozgás a fötéren, vagy hogy épp süt-e a nap otthon.

\section{A munka világa - rejtőzködés nélkül}

A kilencvenes évek migránsainak idóhasználatára épp az volt jellemzó, hogy vagy nem is rendelkeztek szabadidôvel, vagy egy nagyon szúk térre viszszahúzódva töltötték el azt. Ma

már egyre többször találkozunk olyan magatartással, amely a külföldi munkavállalást nem csak a pénzszerzés lehetôségének tekinti, hanem egy másik világgal való megismerkedés alkalmának is legyen szó a másik világ kulturális kínálatairól, természeti adottságairól, szórakozási vagy tanulási lehetôségeiról. A migráns ma már ezeket is igyekszik kihasználni, beélve, megismerve ezzel a másik, az otthonától fizikailag távol lévó helyet. A határok tehát-fizikai és mentális értelemben - valamelyest lebomlanak a transznacionális életforma ezen elemeinek megjelenése által.
A munkavállalás terén nagyon sok olyan változás történt az elmúlt időszakban, amely megváltoztatta a migráns attitüdöket a határátlépések, a terek használatának vonatkozásában. A kilencvenes években szinte kizárólagos feketemunkát lassan felváltotta a hivatalos munkavállalás gyakorlata. Ha nem is szünt meg teljesen az illegális külföldi munkavégzés, mára jóval nagyobb azok száma, akik az érvényben lévő szabályozások alapján hivatalos munkavállalói engedéllyel dolgoznak külföldön. Ez teljesen más térbeélési mechanizmusokat hívott életre. A munkamigráns nem kényszerül rejtőzködésre, a befogadó ország olyan hellyé válik számára, ahol törvényesen tartózkodik és dolgozik. Ez a helyzet lehetővé tesz a hely „beélését", hisz - habár továbbra sem az a hely az otthona - nem a lebukástól való veszély határozza meg az ott-tartózkodást. Az utóbbi években készített interjúkban egyre többen mesélnek arról, hogy szabadidejükben miképp használják ki a befogadó közeg lehetőségeit: utaznak, tanulnak, szórakoznak, vásárolgatnak, sportolnak, ismerkednek a kinti világgal. Nem a bezárkózás jellemző tehát napjaink vendégmunkás-magatartására, hanem egyfajta nyitottság, a térhasználat szabadsága. Ez már egy olyan transznacionális jelleg, amely a szimultán több helyen élést mutatja.

Említettem a szabadidő használatát, ennek megváltozása is figyelemre méltó mozzanat. A kilencvenes évek migránsainak időhasználatára épp az volt jellemző, hogy 
vagy nem is rendelkeztek szabadidővel, vagy egy nagyon szük térre visszahúzódva töltötték el azt. Ma már egyre többször találkozunk olyan magatartással, amely a külföldi munkavállalást nem csak a pénzszerzés lehetőségének tekinti, hanem egy másik világgal való megismerkedés alkalmának is - legyen szó a másik világ kulturális kínálatairól, természeti adottságairól, szórakozási vagy tanulási lehetőségeiről. A migráns ma már ezeket is igyekszik kihasználni, beélve, megismerve ezzel a másik, az otthonától fizikailag távol lévő helyet. A határok tehát - fizikai és mentális értelemben - valamelyest lebomlanak a transznacionális életforma ezen elemeinek megjelenése által.

\section{Mentális közeledések, határbontások}

A befogadó környezethez viszonyuló, a narratívák elemzésekor kibontakozó attitüdökből is az látszik, hogy kevesebb a határmegerősítő mechanizmus. A kilencvenes évek migrációs történeteiben elég gyakoriak voltak a kinti, a külföldi emberekkel kapcsolatos, a nagy történetbe külön kis önálló történetként beillesztett események, amelyek az ellenséges magatartásokat, a lekezelő vagy identitásmegkérdőjelező eseteket „tették helyre” úgy, hogy abból a vendégmunkás ,került ki győztesen”. Úgy tünik, hogy ezekre az utólagos, verbális, narratív „helyretevésekre” sokkal kevésbé van szükség, mint másfél évtizeddel ezelőtt.

Említést érdemel egy másik jelenség is: a munkamigránsok beszámolóiban sokkal több olyan epizóddal találkozunk, amelyek nem az azonnali elutasítást tartalmazzák az idegen világ másságával szemben, hanem reflektáló, megengedő vagy akár elfogadó módon kezelnek az otthoni világtól meröben eltérő, a befogadó környezetben tapasztalt jelenségeket. A befogadó környezet változatos aspektusaival szemben jelentkeznek ezek az új viszonyulások, attól függően, hogy a munkaerőpiac épp melyik területén dolgozik a külföldi munkavállaló: gyermeknevelés, a szabadidő megszervezése, az életvezetés számos eleme, az épített környezet, az emberi kapcsolatok, a munkakörülmények, a mindennapi élet megszervezése, a biztonságos mindennapok és még sorolhatnánk. A negatív megítélések nem tüntek el teljesen, a kritikus megjegyzések továbbra is jelen vannak, de már nem kizárólagos jellemzői az idegen világgal való találkozás megélésének. Az elfogadásnak, a másságra figyelésnek ez a reflektív módja a külföldi munka helyszínét kitágítja (nemcsak a konkrét munkavégzés helye többé), sokkal inkább beélhetővé teszi, mint az elutasító és bezárkózó magatartás.

\section{Összefoglaló gondolatok}

A munkamigráció napjaink társadalmában kiemelkedő intenzitású, dinamikájú, gyakoriságú jelenség. A kérdés vizsgálata nyomán megmutatkoznak azok a trendek is, amelyek nemcsak a dimenziók növekedésére utalnak, hanem a jelenség természetében bekövetkező trendszerü változásokra is rávilágítanak Egy ilyen változás a migráció transznacionalizálódása, amely azt mutatja, hogy a migráló ember képes azonos időben beélni egynél több helyet. A fizikai, kulturális, társadalmi határok átlépése napjaink migránsai számára nem a teljes elszakadást vagy a teljes asszimilálódást jelenti. Kialakíthat egy olyan életformát, amelyben megőrzi kapcsolódását a kibocsátó környezethez, ugyanakkor megteremtheti a kötődéseket a befogadó környezethez is. A Székelyföldön a rendszerváltás óta müködő erőteljes munkamigrációs folyamat is jelzi már a transznacionális migrációnak ezeket a trendjeit. Mind a magatartások, mind a mentalitások szintjén megtapasztalható ez a változás. Az ide irányuló kutatási eredmények arra is felhívják a figyelmet, hogy egy rendkívül komplex jelenséggel állunk szemben, amely a kibocsátó és a befogadó közeg 
szempontjából egyaránt figyelmet érdemel, és - jelen írás fő témájára utalva - elgondolkodásra késztet a különböző természetü határok megerősítésének/gyengítésének, a különböző terek beélési lehetőségeinek változó természetét illetően is.

\section{Irodalomjegyzék}

Biró A. Zoltán (1994): Adalékok a vándorló ember ikonográfiájához. Migrációs folyamatok a Székelyföldön 1985-1989. In: Sik Endre és Tóth Judit (szerk.): Jönnek? Mennek? Maradnak? MTA PTi, nemzetközi Migráció Kutatócsoport évkönyve. Budapest, 19-39. Angol nyelven: Biró, A. Z. (1995): The Socio-Cultural Bases of the Migration Process in Eastern Transylvania, 1985-1989. In: Sik, E. és Tóth, J. (szerk.): Refugees and Migrants: Hungary at a Crossroads. Yearbook of the Research Group on international Migration, the Institute for Political Science of the H.A.s. Budapest. 237-244.

Bodó Julianna (1996, szerk.): Elvándorlók? Vendégmunka és életforma a Székelyföldön. Pro-Print Könyvkiadó, Csíkszereda.

Bodó Julianna (2008): Diskurzusok és életutak a migráció tükrében. Scientia Humana, Budapest.

Bodó Julianna és Biró A. Zoltán (2009): Értékek a transznacionális térben. Székelyföldi munkamigránsok értékorientációi. Antropológiai Mühely, 15. sz. 7-36.

Bodó Julianna (2009): Transznacionális migráció kutatási lehetőségek. In: Bodó Julianna és Kiss Adél (szerk.): Kultúra - kommunikáció - innováció. A KAB Alkalmazott Társadalomtudományi Szakbizottság konferenciái. Csikszereda, 2008. október 10., Csikszereda, 2009. október 29. Státus Kiadó, Csíkszereda. 32-40.
De Haas, H. (2009): Mobility and Human Development. UNDP, New York.

De Haas, H. (2010): Migration and development: a theoretical perspective. International Migration Review, 44. 1. sz. 1-38.

DOI: $10.1111 / \mathrm{j} .1747-7379.2009 .00804 . \mathrm{x}$

Glick Schiller, N., Basch, L. és Szanton, B. C. (1997): From Immigrant to Transmigrant: Theorizing Transnational Migration. In: Pries, L. (szerk.): Transnational Migration. Sociale Welt. Sonderband 12. NOMOS, Baden-Baden.

Niedermüller Péter (2005): A lokalitás metamorfózisai. Replika, 56-57. sz. 33-44.

Malkki, L. (2006): Nemzeti földrajz: A népek gyökerei és a nemzeti identitás territorializálás a tudományos irodalomban és a menekültek között. Replika, 56-57. sz. 61-80.

Oláh Sándor (1996): A kilépés társadalmi feltételei a Székelyföldön. In: Bodó Julianna (szerk.): Elvándorlók? Vendégmunka és életforma a Székelyföldön. ProPrint Könyvkiadó, Csíkszereda. 51-68.

Schiffauer, W. (2004): Félelem a különbözőségtől. Új áramlatok a kultúr- és szociálantropológiában. In: Biczó Gábor (szerk.): Az idegen. Variációk Simmeltől Derridáig. Csokonai Kiadó, Debrecen. 151-161. 